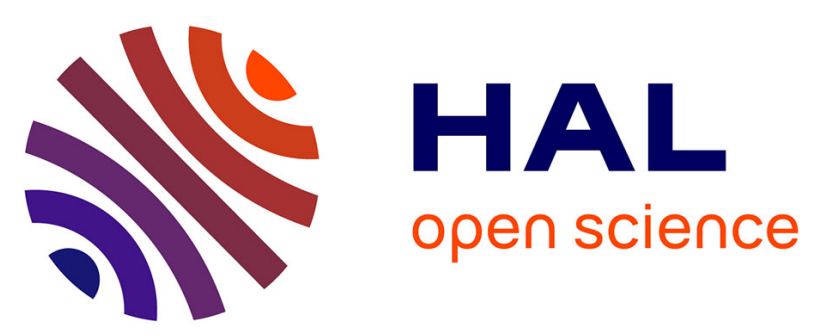

\title{
An unexpected record of the PETM in terrestrial and organic sediments of Avesnois, between the Paris and Belgian Basins, NW Europe
}

\author{
Christian Dupuy, Florence Quesnel, Jean-Marc Baele
}

\section{To cite this version:}

Christian Dupuy, Florence Quesnel, Jean-Marc Baele. An unexpected record of the PETM in terrestrial and organic sediments of Avesnois, between the Paris and Belgian Basins, NW Europe. Climatic and Biotic Events of the Paleogene meeting: CBEP 2014, Jul 2014, Ferrara, Italy. pp.68-69, 10.3301/ROL.2014.49 . hal-01010549

\section{HAL Id: hal-01010549 https://hal-brgm.archives-ouvertes.fr/hal-01010549}

Submitted on 20 Jun 2014

HAL is a multi-disciplinary open access archive for the deposit and dissemination of scientific research documents, whether they are published or not. The documents may come from teaching and research institutions in France or abroad, or from public or private research centers.
L'archive ouverte pluridisciplinaire HAL, est destinée au dépôt et à la diffusion de documents scientifiques de niveau recherche, publiés ou non, émanant des établissements d'enseignement et de recherche français ou étrangers, des laboratoires publics ou privés. 


\title{
An unexpected record of the PETM in terrestrial and organic sediments of Avesnois, between the Paris and Belgian Basins, NW Europe
}

\author{
Florence Quesnel $^{(\mathrm{a}, \mathrm{b})}$, Jean-Yves Storme ${ }^{(\mathrm{c})}$, Emile Roche $^{(\mathrm{c})}$, Alina Iakovleva ${ }^{(\mathrm{d})}$, Pieter Missiaen $^{(\mathrm{e})}$, Thierry Smith $^{(\mathrm{f})}$, Chantal \\ Bourdillon $^{(\mathrm{g})}$, Jean-Marc Baele ${ }^{(\mathrm{h})}$, Johan Yans ${ }^{(\mathrm{i})}$, Johann Schnyder ${ }^{(\mathrm{j})}$, Paola Iacumin ${ }^{(\mathrm{k})}$, Christine Fléhoc ${ }^{(\mathrm{l})}$ \& Christian Dupuis ${ }^{(\mathrm{h})}$
}

\footnotetext{
(a) BRGM (French Geological Survey), Georesources Division, Land Use Geology Unit, 3, Avenue Cl. Guillemin, 45060 Orléans Cedex 2, France. E-mail: f.quesnel@ brgm.fr ( ) UMR 7327 of the CNRS/INSU, Orléans University \& BRGM, 1A, rue de la Férollerie, 45071 Orléans, France. E-mail: f.quesnel@brgm.fr

( $\left.{ }^{c}\right)$ Geology Dept, Palaeobiogeology-Palaeobotany-Palaeopalynology, Liège University, Allée du 6 Août, 17, 4000 Liège Sart-Tilman, Belgium. E-mail: jystorme @ulg.ac.be \& rocheemile@yahoo.fr

(d) Geological Institute, Russian Academy of Sciences, Pyzhevsky pereulok 7, 119017 Moscow, Russia. E-mail: alina.iakovleva@gmail.com

(e) Research Unit Palaeontology, Ghent University, Krijgslaan 281, S8, B-9000 Ghent, Belgium. E-mail: pieter.missiaen@gmail.com

(5) O.D. Earth \& History of Life, Royal Belgian Institute of Natural Sciences, Vautierstraat 29, 1000 Brussels, Belgium. E-mail: thierry.smith@ naturalsciences.be

$\left({ }^{\mathrm{g}}\right)$ ERADATA, 170, Avenue Félix Gesnelay, 72100 Le Mans, France. E-mail: bourdillon@eradata.fr

${ }^{\text {h) }}$ Geology and Applied Geology, Faculty of Engineering, University of Mons, 20, Place du Parc, 7000 Mons, Belgium. E-mail: christian.dupuis@ umons.ac.be \& jean-

marc.baele@umons.ac.be

(i) University of Namur, Department of Geology, Rue de Bruxelles, 61, 5000 Namur, Belgium. E-mail: johan.yans@ fundp.ac.be

(j) ISTeP, Pierre \& Marie Curie University-Paris 6, 4, Place Jussieu, 75252 Paris cedex 05, France. E-mail: johann.schnyder@ upmc.fr

$\left.{ }^{k}\right)$ Earth Sciences Department, Parma University, Viale G.P. Usberti, 157/A, 43100 Parma, Italy. E-mail: paola.iacumin@ unipr.it

(') BRGM (French Geological Survey), Laboratory Division, Isotopes Unit, 3, Avenue Cl. Guillemin, 45060 Orléans Cedex 2, France. E-mail: c.flehoc@ brgm.fr
}

KEY WORDS: Avesnois, Belgian \& Paris Basins, Carbon Isotope Excursion, faunal \& floral changes, palynology, PETM, stratigraphy

The stratigraphy of the Late Paleocene-Early Eocene has been revised in Avesnois thanks to drillings supporting a geological mapping project. Detailed sampling and analyses were performed along selected drillings, among which sedimentological, mineralogical, chemostratigraphic $\left(\delta^{13} \mathrm{C}_{\text {org }}\right)$, biostratigraphic and palynological data have been obtained. New Mbs/Fms are defined around the Paleocene-Eocene boundary (PEb) and compared to the lithostratigraphic nomenclatures of the Belgian and Paris Basins (Steurbaut, 1998; Aubry et al., 2005). Biostratigraphy based on the study of foraminifera and mammal fauna, palynological content and chemostratigraphy enable correlation to be established between adjacent basins as well as sea level and landscape evolutions to be refined during this critical interval.

\section{Upper Thanetian marine units}

In the AVE 007-drilling (Mormal Forest, Locquignol, between Englefontaine, Landrecies and Maroilles villages), the Coniacian chalk is overlain by a flint conglomerate, whose sandy-clayey matrix contains Thanetian pollen and dinocysts. Widespread in Avesnois and containing often reworked Upper Cretaceous foraminifera and occasionally glauconite, this unit constitutes the Vervins Mb (cf. 'Argile à silex de Vervins' interpreted as a marine conglomerate by Gosselet, 1879). It is often overlain by the Mondrepuis-Bettrechies Sand Mb (cf. 'Sable verts de l'Avesnois'), a thin sandy glauconiferous unit, more clayey and silty westward (cf. 'Tuffeau de Valenciennes' Mb). The three Mbs constitute the HainautValenciennois $\mathbf{F m}$ and can be correlated to the Belgian Grandglise $\mathrm{Mb}$ (upper part of the Hannut Fm) and Bois-Gilles Fm, and to the Paris Basin Châlons-sur-Vesles and Bracheux Fms, all Thanetian in age.
Uppermost Paleocene to lowermost Eocene terrestrial units

In AVE 007 the Vervins Mb is unconformably overlain by flint gravels (Mormal Mb), then a pyritic sand (Le Quesnoy Sand Mb, cf. 'Sables et Grès du Quesnoy' of Gosselet, 1890), and a lignitic clay (Locquignol Mb), silty and ochreous at the top. All but the top ochreous paleosol contain spores and pollen grains and are devoid of dinocysts, they were thus probably deposited in terrestrial environments. The Carbon Isotope Excursion (CIE) of the PEb begins below the top of the sandy unit and continues in the lignitic clay. The palynological study confirms the Locquignol Mb's earliest Eocene age and allows correlation with the base of the Tienen Fm.

To the East of AVE 007 along the Belgium-France border, fluvial fossiliferous gravels and sands have been studied in past sand quarries (Erquelinnes Sand Mb). Above a sharp unconformity, they i) overly Upper Thanetian marine sands (Bois-Gilles Fm, NP9a, then Grandglise Mb, NP8), ii) contain a mammal fauna referred as MP7 in the Mammalian biochronological scale for the European Paleogene (Missiaen et al., 2013) and iii) record the first part of the CIE onset in the basal fossiliferous gravel and marl beds.

Three km west of Erquelinnes and toward AVE 007 a few drillings have recognized a sandy and pyritic unit containing resinite fragments, lignite and peat beds (Vieux Reng Mb), overlying a thin basal flint gravel bed (Mormal Mb).

These five Mormal, Le Quesnoy, Locquignol, Vieux-Reng and Erquelinnes Sand Mbs form the Sambre Fm. Such fluvial gravels and sands, more or less lignitic, clayey or marly are widespread in northern France and southeastern Belgium. They belong to the so-called Upper "Landenian" and are correlated to the Tienen Fm. In AVE 007, they record the CIE onset marking the $\mathrm{PEb}$ and $2.5 \mathrm{~m}$ of Upper Paleocene fluvial units, in contrast with Belgian drillings such as Doel and Kallo where a hiatus is present at the $\mathrm{PEb}$. 


\section{Lower Ypresian hiatus and marine units}

In AVE 007, a laminated silty unit overlies the Locquignol $\mathrm{Mb}$, contains dinocysts Wetzeliella $s p$. and agglutinated foraminifera similar to those of the base of the Orchies Clay Mb. Widespread in Avesnois-Valenciennois that marine unit is named Avesnois Mb, it is locally richer in very fine sand, and correlated to the base of the Kortrijk Clay Fm (Ieper Gp).

In Avesnois, Sparnacian lagoonal units are absent upon the terrestrial ones described above, again marking a reverse trend when compared with the Belgian and adjacent Basins. This may result from restricted terrestrial environments coinciding with Variscan accidents and structural highs between the Artois anticline and Ardenne Masssif, or to their deposition followed by subsequent erosion prior to the Lower Ypresian marine transgression (cf. sea level drop 2 of Dupuis et al, 2011).

\section{Correlations and PETM impact on land}

All terrestrial units here described fill fluvial channels incised in marine Thanetian and older units such as the Cretaceous or the Variscan basement in Avesnois and Belgium, as already reported elsewhere in northern France (cf. sea level drop 1 of Dupuis et al., 2011). They exhibit locally cross stratification, lignite, flora or vertebrate fauna, for example at Leval, Hoegaarden and Dormaal, and/or are intensively silicified with scarce root or leaf casts.

Similar fluvial sediments and silcretes are recognized in the first Sparnacian units and paleogeography of the Paris, DieppeHampshire and London Basins, where the PEb is also present, the CIE being recorded on thicknesses between $3 \mathrm{~m}$ (as in AVE 007) to $>20 \mathrm{~m}$ (as in Sinceny). These features may be regarded now as constant in those Sparnacian landscapes recording the PETM, with very rapid lateral and vertical facies shift, particular paleosols, a few fossiliferous fluvial to lacustrine units and variable deposition rates/sediments preservation.

Terrestrial sediments, flora and fauna have been described there before the CIE onset as well, for example at Cobham, Vasterival or Rivecourt (e.g. Smith et al., 2014). Lihons, an intermediate outlier situated between AVE 007 and Sparnacian sites of those basins has further been investigated: marine Thanetian sands are overlain by thin fluvial, lacustrine then lagoonal sediments, the two latter recording the CIE of the PETM on an interval $4 \mathrm{~m}$ thick. Here again the basal terrestrial sediments have been deposited before the PEb.

In AVE 007, depositional environments are fluvial for the Mormal and Le Quesnoy Mbs, and evolve toward flood plain then palustrine ones for the Locquignol $\mathrm{Mb}$, probably here after the river bed migration, but still recording sporo-pollen fluvial inputs from the hinterland, the whole indicating a rather humid subtropical climate. Compared to the Locquignol $\mathrm{Mb}$, the sporopollinic assemblage of the Mormal and Le Quesnoy Mbs (below the CIE onset) is different, particularly regarding the Normapolles distribution, the Tricolpates, Tricolporates and Monocolpates relative pollen abundances and the pollen ratio of Plicapollis pseudoexcelsus/Juglandaceae.

In the three Mbs, rapid vertical variations characterize pollen and fern spores assemblages, with peaks of particular taxa reaching $25 \%$ of the total counts, such as for $P$. pseudoexcelsus, $\quad T$. platycaryoides, $C$. dorogensis, $P$. mcgregorii, $T$. robustus. They suggest rapid floral changes in the catchment and/or sources changes in the surrounding landscapes compartments for the rivers supplying the fluvial sediments. Resinite particles are irregularly abundant as well as microcharcoals are occasionally abundant, notably slightly before the CIE onset and $1.5 \mathrm{~m}$ above it, still within the CIE.

The clay mineral assemblage is homogeneous along marine Thanetian units and strongly dominated by Illite-Smectite (IS) mixed layers, whatever the facies, while it is more variable in the marine Ypresian silts (abundant IS, followed by Kaolinite, Illite, Chlorite and Vermiculite). In contrast terrestrial units are dominated by IS followed by Kaolinite, Illite and very rare Chlorite, and no variation is observed across the PEb.

Those data would suggest that major environmental changes have regionally begun before the PETM, at the very end of the Paleocene, when terrestrial realm has settled, in relation with a regional uplift. Clay minerals reflect constant reworking of preexisting weathering profiles established upon Cretaceous strata and Variscan basement, while vegetation modifications are subtle and more likely attributable to changes of depositional environments.

\section{REFERENCES}

Aubry M.P., Thiry M., Dupuis Ch. \& Berggren W.A. (2005) The Sparnacian deposits of the Paris Basin: A lithostratigraphic classification. Stratigraphy, 2 (1), 65-100.

Dupuis C., Quesnel P., Iakovleva A.I., Storme J.Y., Yans J. \& Magioncalda R. (2011) - Sea level changes in the Paleocene-Eocene interval in the NW France: Evidence of two major drops encompassing the PETM. In: Egger $\mathrm{H}$. (ed.), CBEP 2011, Conference Program and Abstracts, 5-8 June 2011, Salzburg, Austria. Berichte der Geologischen Bundesanstalt, 85, 68.

Gosselet J. (1879) - L'Argile à silex de Vervins, Annales de la Société Géologique du Nord, VI, 317-339, 1 planche.

Gosselet J. (1890) - Relations entre les sables de l'Eocène Inférieur dans le Nord de la France et dans le Bassin de Paris, Bull. Serv. Carte Géol. de la France et des topographies souterraines, 8, janvier 1890, 1-16.

Missiaen P., Quesnel F., Dupuis C., Storme J.-Y. \&Smith T. (2013) - The earliest Eocene mammal fauna of the Erquelinnes Sand Member near the French-Belgian border. Geologica Belgica, 16/4, 262-273.

Smith T., Quesnel F., De Ploëg G., De Franceschi D., Métais G., De Bast E., Solé F., Folie A., Boura A., Claude J., Dupuis C., Gagnaison C., Iakovleva A.I., Martin J., Maubert M., Prieur J., Roche E., Storme J.-Y.,Thomas T., Tong H., Yans J. \& Buffetaut E. (2014) - First Clarkforkian equivalent Land Mammal Age in the latest Paleocene basal Sparnacian facies of Europe: fauna, Flora, paleoenvironment and (bio)stratigraphy. PLoS ONE 9(1): e86229, 20 p. Doi:10.1371/journal.pone.0086229

Steurbaut E. (1998) - High resolution holostratigraphy of Middle Paleocene to Early Eocene strata in Belgium and adjacent area, Palaeontographica, A 247, 91-156. 
Rend. Online Soc. Geol. It., Vol. XX (2014), pp. XX-XX,

(C) Società Geologica Italiana, Roma 2014 